\title{
FORUM
}

\section{THE COMMITMENTS OF DEMOCRACY}

\author{
DANIEL T. RODGERS \\ Department of History, Princeton University \\ E-mail: drodgers@princeton.edu
}

James T. Kloppenberg, Toward Democracy: The Struggle for Self-Rule in European and American Thought (New York: Oxford University Press, 2016)

It underplays the significance of James Kloppenberg's monumentally ambitious and massively learned Toward Democracy to call it a big book-though at seven hundred pages of text, a hundred pages of notes and another five hundred pages of additional endnotes online it is surely that. It is, in voice and subject, several books in one. The first is a sweeping narrative account of the struggles for self-rule in England, the United States, and France from the seventeenth century through the middle third of the nineteenth century. The great revolutions stand at this history's center-the Puritan Revolution of the 1640s, the British North Americans' revolt against monarchy and their construction of an enduring kingless polity in the 1770 s and 1780s, and the revolutionary upheaval in France in the years after 1789- their origins, struggles, and dramas etched with a skilled narrative historian's hand.

The second book within Toward Democracy is a comparative analysis of the outcomes of democratic revolution on both the European and North American sides of the Atlantic. Conducted in watchful observation of one another and fueled by transnationally circulating ideas and programs, these struggles left behind, nonetheless, radically different legacies. Three decades ago, Kloppenberg's nowclassic Uncertain Victory wound the history of ideas and politics in late nineteenthand early twentieth-century Europe and the United States around a story of convergence. ${ }^{1}$ Here, though he describes Toward Democracy as a "postexceptionalist" history (5), American divergence from the European norm is the controlling frame. ${ }^{2}$ Stripped of the immense weight of hierarchical institutions

James T. Kloppenberg, Uncertain Victory: Social Democracy and Progressivism in European and American Thought, 1870-1920 (New York, 1986).

2 Throughout this forum, references to Kloppenberg's Toward Democracy will be given parenthetically. 
that bore down on them socially and politically in Europe, structures of local governance that would have been impossible to sustain elsewhere slipped into custom and practice in British North America. When ambitions for popular rule came to a head in Europe, they smashed up against structures of monarchy, church, and society that were barely present in British North America-first to be deformed by the unextinguished passions of centuries of religious warfare, finally to be defeated by the powers they hoped to overturn. In British North America, the outcome of revolution was an imperfect democracy. In France and England, Kloppenberg argues, the tumultuous consequence of revolution was to set back the further development of democracy altogether for a century or more.

The third book within Toward Democracy, woven within these first two, is a careful, unfailingly intelligent account of the major figures who wrote and thought their way through these contentious struggles, trying to give a frame and a rationale for kingless, popular government. Many of these are familiar characters, some much less so. But whether it is in an account of the Levellers' pamphlet wars in the 1640s, the efforts of French political theorists to work out the principles of representation as the monarchy tottered around them in the 178 os, or the American debates over the constitutional design of a workable republic in the 1770 s and 1780 s, Kloppenberg draws these debates and the figures at their center with a subtlety and clarity honed on years of scholarly accomplishment.

The fourth book within Toward Democracy is an ethical account of what democracy should be and the values it must embrace. For all its historical twists and turns, for all its inner tensions and contests, democracy, Kloppenberg insists, is not whatever majorities claim it to be. Democracy entails three core principles: the principle of popular sovereignty, the principle of individual autonomy, and the principle of equality. Beyond these, and even more indispensable to its survival, Kloppenberg urges, democracy entails three ethical commitments: a commitment to deliberation, a provisional understanding of truth which resists the temptation to impose a unitary conception of the good life on others, and a commitment to mutuality and reciprocity. It is these that draw democracy-if it be worth its name-back from any merely mechanical aggregation of the preferences of the greater number.

For readers of this journal, the third of these books within Toward Democracy will draw their quickest attention and give correspondingly generous rewards. The closeness with which the figures in these three polities observed each other helps bring the political dimensions of the North Atlantic intellectual world into powerful focus. Writers, critics, political philosophers, and constitution drafters in all three countries ran up against common questions. How was sovereignty effectively to be devolved from absolute monarchs to the people? How was 
democratic power to be distributed? How were countervailing powers to be constrained? How were the customs and everyday practices upon which kingless government depended to be inculcated among the people? Their search for answers formed a wide-ranging and fluid terrain of debate. Through argument, invention, intellectual contention, and deliberation, Kloppenberg shows, even more than in the clash of armies and the mobilization of the urban crowds and rural masses, a new democratic ideal was born.

None of the figures in Toward Democracy's huge canvass emerge as persons of a single idea. Kloppenberg's treatment of James Madison is an apt example of the way in which a gifted intellectual historian can rescue a historical figure from the singular "idea" to which later writers regularly reduced them, simplifying them into intellectual cartoons for a later moment's purposes. The Madison who authored the principle of countervailing powers, the man fearful of unchecked majority rule and faction who devised a constitution whose own internal machinery might cancel out the worst temptations of democracy, was not the only Madison, Kloppenberg insists. Madison wrote as seriously as any of his contemporaries of the "public" weal and the "common good." Discernment of the "common good of the society," he wrote in Federalist no. 57, should be the first aim of every political constitution. He believed in deliberative politics, in an ethic of compromise and forbearance, not simply in means to automatically cancel out the momentary lust of majorities.

In passages like these, Toward Democracy makes clear how thoroughly intellectual history now inhabits its post-Pocockian moment. The tightly constructed political "languages" that not so long ago seemed to frame and bifurcate eighteenth-century political debate are a thing of intellectual history's past. The contending forces in Kloppenberg's account are not "liberalism" and "republicanism" but men and women thinking their way eclectically through the range of questions that revolutionary politics thrust upon them. They lived not amidst binaries, but much more complex, shifting contingencies-amidst the deliberation and debate, in short, which Kloppenberg insists forms the very essence of democracy.

Throughout most of Toward Democracy, the unstable dynamics of democracy's intellectual life take center stage. "There is no single, essential, unchanging idea of democracy," Kloppenberg writes. Its key elements were all contested (6). "Disagreements about democracy constitute its history" (5). The voice of book four, however, is different. There Kloppenberg urges his readers to think beyond this swirl of contentions and contingencies and to see an "ethical ideal" in construction. Full of shortcomings, ironies, and unexpected consequences as it was, the history of democracy nonetheless possesses "a certain directionality" (14). Commitments to popular sovereignty, to individual autonomy, to equality, to deliberation, to a provisional understanding of truth, and to mutual reciprocity 
were not chance aggregations. Morally, philosophically, and historically they were all entailed in each other.

Through this line of argument Kloppenberg wants to give his readers a way to sort out the false claimants to democracy from the truer, deeper representatives of the democratic ideal. Democracy, he insists, is neither a majoritarian numbers game nor a mere marketplace of preferences. Voting is not its key but the deliberation by which projects for the common good may be drawn out of the immense variety of interests and moral claims that popular government releases. Dreams of a singular common will, which doomed the French Revolution to failure, were fatal to the democracy ideal everywhere. But so were the partisans of mere majority-empowered force: the Jacksonians, whose racism and whose hijacking of the democratic label Kloppenberg excoriates, the Radical Republicans whose vindictiveness he fears cut off democratic possibilities in the postwar South, the self-satisfied bourgeoisie which monopolized the suffrage in nineteenth-century Britain, or the "scrambling individualists" of the American Gilded Age.

Writing in this mood, Kloppenberg wants us to see the ingredients of democracy inscribed not only in the logic of its premises but in democracy's history itself. His sketches of the democratic ideal's key intellectual figures pull hard on threads of deep continuity. Lincoln's response to Stephen Douglas at their Peoria debate, Kloppenberg writes, was "as old as the Christian scriptures, the Puritans' ideal of ordered liberty and their conception of the public good, the Scottish philosophers' idea of sympathy, and the insistence of John Adams, Madison, and Wilson that, as Rousseau saw, the purpose of democracy is to identify and advance the common interest" (659). It "embraced the view of thinkers ranging from the founders of New England towns and the Levellers through Rousseau and Madison to Tocqueville and Mill" (692). Democracy is a contest. Democracy is a parade. Conceivably it is something of both.

But were all of the ingredients that we, too, responding to the powerful example of Kloppenberg's moral sympathy, would like to see as hanging together in fact logically or ethically contained in each other? Commitment to equality surely spelled an end to absolute monarchy. But commitment to democracy did not necessitate a corresponding commitment to equality. Democracy has had a boundary problem from its very first beginnings. Who stands within the circle of the people whom democracy will empower? Who stands outside on some lower rung of social and political status? Virtually none of the figures in Toward Democracy's pages - from the Athenians who popularized the term "democracy," to the organizers of the early New England town meetings which Kloppenberg deeply admires, to Abraham Lincoln himself_-believed that all adult persons were equal. Nor did they believe that their commitment to self-rule or the people's sovereignty required them to think so. 
Democracy has a competency problem as well. Into what domains should the sphere of the people's rule extend? Across all the spheres of justice and administration or only some of them? How deeply into the life and consciences of persons should its competency reach? Democracy has a representation problem. Who may speak in the people's name and through what means should they be chosen? Democracy has, not the least, a relationship problem. With what degree of adversarialism, what degree of comity, what degree of tolerance when some things seem intolerable, should it proceed? For all the borrowed language between them, these were distinctly separate struggles, initiated by distinctly different and differently situated persons. An appeal to the democratic ideal's inner core, or the mutual entailments of its premises, or a line of historical continuity, cannot adequately contain these histories within a single compass, however capacious.

The extraordinary seriousness with which Toward Democracy attempts the task of holding its historical and ethical commitments together cannot be slighted. More than most other figures in the profession, James Kloppenberg has been an eloquent voice for the claim that intellectual history and moral philosophy cannot be separated from each other without deep costs to both. But democracy as it has been and democracy as we would wish it to be, and wish our best thinkers to have already implicitly imagined it to be, are not the same thing. Working both tasks out within the frame of single book, however massive, bears risks for both sides of the project.

For my part, I found myself most moved by Kloppenberg's voice as the moral philosopher of mutuality. Toward Democracy opens with a poignant sketch of Montaigne writing in lonely isolation in a world inflamed by religious warfare. Creedal passions consumed his neighbors. Armies burned and marauded across the countryside. Montaigne himself was kidnapped; his execution was plotted. But in that cauldron of certainties and passions Montaigne put his trust in doubt and restraint. He worked to embody what Kloppenberg calls an ethic of reciprocity, a willingness to see himself in another's place that was ultimately more courageous than militant courage itself. Toward Democracy's other bookend is Abraham Lincoln's Second Inaugural-Lincoln's short (and to many listeners deeply enigmatic) reflection on fate and complicity as the Civil War ground on beyond a cost that anyone had conceived possible.

"Surely the most eloquent statement of democratic principles in the American record," Kloppenberg calls Lincoln's text (697). In fact, “democracy” went utterly unstated in Lincoln's Second Inaugural. The appeals to equality that Lincoln had made so eloquently at Gettysburg sixteen months earlier were shelved for the occasion as well. The outcome to which his listeners might look forward, beyond the patching together of a bleeding nation, was left wholly unclear. Lincoln's was a statement of resignation and humility. Let us not judge. Let us 
not imagine that God hears the prayers of only one of the sides locked in this terrible violence. Lincoln's Second Inaugural spoke eloquently to the mood of forbearance that Montaigne had penned almost three centuries earlier. Lincoln did not mention democracy. Montaigne despised it. They spoke for an ethics of uncertainty, a relinquishment of self-righteousness, a sympathy across chasms of anger, a mutuality that Kloppenberg want us to take deeply and seriously.

A culture of mutual forbearance, discourse, and compromise does not, by itself, constitute a democratic culture. If the crushing of American slavery inaugurated, at last, the beginnings of democracy in the American nation, it took stubbornness and courage of a more old-fashioned kind to set it in motion. It took its Garrisons, its Frederick Douglasses, even its Nat Turners. But reading Toward Democracy in the immediate wake of the 2016 election, in a world that has all but normalized perpetual war, when a politics of insult and raw emotion, racist and xenophobic taunts and angry certainties, seems to have erupted unchained across contemporary America and much of Europe as well, these reminders of the virtues of reciprocity, mutuality, and respect are all the more powerful and all the more needed. In that, above all, this is not only a big and ambitious book but a book with a deep moral ballast and importance. 